\title{
Effects of High Performance Work Systems on Employee Performance: Psychological Contract Breach as Mediator
}

\author{
Zhu-xiaomei \\ Antai College of Economics \& Management \\ Shanghai Jiao Tong University \\ Shanghai, China \\ xiaomeizhu99@163.com
}

\author{
Zhou-huanqing, Kong-lingwei \\ College of Economics \& Management \\ East China Jiao Tong University \\ Nanchang, China
}

\begin{abstract}
Based on the thorough review of the past research on high performance work systems and psychological contract, this paper examines the relationship among high performance work systems, psychological contract breach and employee performance, using data of 630 employees. Results show that high performance work systems have a significant effect on employee performance. Furthermore, psychological contract breach mediated the relationship between high performance work systems and in-role performance and $\mathrm{OCB}$.
\end{abstract}

Keywords-high performance work systems; psychological contract breach; in-role performance; $O C B$

\section{INTRODUCTION}

High performance work systems (HPWS) have been playing a key role in the achievement of business goals and improved organizational effectiveness (Becker and Huselid, 2006; Macky and Boxall, 2007). Authors in the field consistently concern that the mechanisms through which high performance work systems influence organizational performance (Delery, 1998; Wright et al., 2005; Paauwe and Boselie, 2005). Commitment, empowerment, and self-control are at the heart of "high performance work systems" that seem to provide "optimal" HRM systems (Arthur, 1994; Huselid, 1995; Appelbaum et al.,2000, Boxall and Macky, 2009).

Moreover, individual level HRM performance research, mostly taking a psychological perspective, has been more effective in linking individual's characteristics to a variety of outcome variables such as intention to leave the organization, employee satisfaction, and various types of commitment (Robinson and Morrison, 2000; Turnley and Feldman, 2000; Tekleab and Taylor, 2003). Psychological contracts is defined as "individual beliefs, shaped by the organization, regarding terms of an exchange agreement between individuals and their organization"(Rousseau, 1995). Breach of the psychological contract has been empirically linked to a number of attitudes and behaviours, such as job satisfaction, intention to leave, job performance, and OCB (zhao et al., 2007).

Therefore, the objectives of this study were to examine the potential mediating influence of psychological contract breach (PCB) on the relationship between high performance work systems and employee performance. The study will enrich the theories of high performance work systems and psychological contract, as well as provide the practical directions to human resource management and psychological contract management

This study is supported by a NSFC grant No. 71162006, 71132003; Fund of post-PhD grant No. 2012M510853. in organization.

\section{LITERATURE REVIEW}

A. High performance work systems and employee performance

High performance work systems refer to a group of separate but interconnected HRM practices, including comprehensive recruitment and selection procedures, incentive compensation and performance management systems, and extensive employee involvement and training, which are designed to enhance employee and firm performance outcomes through improving workforce competence, attitudes, and motivation (Huselid, 1995). Some studies investigated the effect of individual HRM practices, whereas others tested bundles or systems of HRM practices. Both kinds of approaches supported the expected relationship between high performance work systems and organizational performance (e.g. Delery and Doty 1996; Delaney and Huselid 1996; Raeder, Knorr, and Hilb, 2012). High performance work systems influence and align employees' attitudes and behaviors with the strategic goals of the organization and thereby increase employee commitment and subsequently organizational performance (Schuler and Jackson, 1987). Therefore, high performance work systems are a configuration of HRM practices designed to increase employee commitment and subsequently performance (Becker and Huselid, 2006; Bowen and Ostroff, 2004).

\section{B. High performance work systems and psychological contract}

Psychological contracts are individually held perceptions regarding exchange agreements between employees and organizations (Rousseau, 1995). Researchers acknowledge that psychological contracts develop at key moments in the employment relationship, such as recruitment, performance appraisal, training, and compensation discussions and outcomes (e.g. Rousseau and McLean Parks, 1993; Robinson et al., 1994) or during events where organizations express plans for the future (Rousseau, 1995). Human Resource departments of organizations, through their policies, practices and actions aimed at managing and shaping the employment relationship, are therefore considered to be particularly instrumental in the shaping of psychological contracts (Rousseau, 1995; Westwood et al., 2001; Koene and Van Riemsdijk, 2005). Some even state that the task of HRM should be the creation and maintenance of the psychological 
contract between organizations and their employees, where each HRM practice represents a choice by the organization about what it expects from its employees and what the employees can expect in return (Sparrow, 1998).

High performance work systems will influence perceptions of psychological contact breach for two reasons. First, high performance work systems often indicate good intentions on behalf of the employer. If some expectations fail to materialize, the employee may experience an adverse psychological reaction. Second, high performance work systems are expected to generate more consistent messages than individual HRM practices (Bowen and Ostroff, 2004). As a result, it is possible that employees will look to these bundles as ongoing investments that they will keep track of as "kept" or "not kept."

\section{Psychological contract and employee performance}

Several studies as well as a recent meta analysis reported a correlation between the psychological contract and employee performance, which is positive for the fulfillment and negative for the breach of the psychological contract (e.g. Robinson 1996; Lester, Turnley, Bloodgood and Bolino 2002; Turnley et al. 2003; Zhao, Wayne, Glibkowski and Bravo 2007). A vast amount of research suggest that psychological contract breach has negative impact on poor citizenship behavior, reduced job satisfaction, and intentions to quit and so on (Blomme et al., 2010; Chen et al., 2008; Orvis et al., 2008; Suazo, 2009).

Both in-role performance and OCB are important components of employee performance (Barksdale and Werner, 2001). In-role performance is defined as being part of one's job is recognized by the organization's formal reward systems (Katz \& Kahn, 1978). According to the norm of reciprocity, (Gouldner, 1960), when the employer violates its obligations, the employee may reduce their efforts and performance. Thus, we propose the following:

H1 The relationship between high performance work systems and in-role performance will be mediated by psychological contract breach.

OCB has been defined as individual behaviors that are discretionary, beneficial, not directly or explicitly recognized by the formal reward system. Therefore, employees will engage in OCB to reciprocate the organization's fair treatment and withhold OCB when they perceive a negative relationship with their employer(Organ, 1988, 1990). Most previous research have examined the negative impact of psychological contract breach on OCB (e.g. Robinson\& Morrison, 1995). Thus, we propose the following:

H2 The relationship between high performance work systems and OCB will be mediated by psychological contract breach.

$\mathrm{H} 2 \mathrm{a}$ The relationship between high performance work systems and OCB-I will be mediated by psychological contract breach.

$\mathrm{H} 2 \mathrm{~b}$ The relationship between high performance work systems and OCB-O will be mediated by psychological contract breach.

\section{METHOD}

\section{A. Sample}

Sample was composed of eight hundred employees. Six hundred thirty surveys were returned, and the response rate was $78.8 \%$. Of the respondents, $34.2 \%$ were women, $65.8 \%$ were men; $56.2 \%$ were $20-29$ years old; $34.0 \%$ were $30-39$ years old; $8.1 \%$ were $40-49$ years old, $1.6 \%$ were beyond 50 years old. The education level of the respondents varied: $6.8 \%$ had some college training, $48 \%$ had a bachelor's degree, $38.5 \%$ had a graduate degree, and $6.7 \%$ had a doctor degree. The respondents' average years of work experience as follow: $0-1$ year $(13.2 \%)$; $1-3$ years $(20.4 \%), 3-5$ years $(26.6 \%) ; 5-10$ years $(19.4 \%)$; beyond 10 years $(20.4 \%)$.

\section{B. Measures}

High performance work systems (HPWS). High performance work systems were assessed by fifteen items, which provided by Xiao \& Bjorkman (2010). Such as, "careful selection procedures in recruiting"; "enlarged jobs and job rotation"; "extensive ownership of shares, options or profitsharing". Participants rated each item using a five-point Likert scale (1="Strongly Disagree"; 5="Strongly Agree"). Cronbach's alpha for this scale was 0.88 .

Psychological contract breach $(P C B)$. Psychological contract breach was measured using five-item scale developed by Robinson \& Morrison (2000). A sample item is "I feel that my employer has come through in fulfilling the promises made to me when I was hired". Participants rated each item using a five-point Likert scale (1="Strongly Disagree"; 5="Strongly Agree"). Cronbach's alpha for this scale was 0.81.

In-role performance (IRP). In-role performance was measured using the seven-item in-role behavior scale provided by Williams and Anderson (1991). An example of an item is "I meet the performance requirements of the job." All responses were made on a five-point Likert scale (1="Strongly Disagree"; 5="Strongly Agree"). Cronbach's alpha for this scale was 0.82 .

Organizational citizenship behaviors $(O C B)$. This scale is composed of two aspects. Organizational citizenship behaviors directed toward the whole organization (OCB-O), and organizational citizenship behaviors directed at other individuals (OCB-I) were assessed using 14 items developed by Williams and Anderson (1991). For example, "I adhere to informal rules to maintain order"). Participants rated each item using a five-point Likert scale (1="Strongly Disagree"; 5="Strongly Agree"). Cronbach's alpha for the seven-item OCB-I scale was 0.67. Cronbach's alphas for the seven-item OCB-O were 0.70 . Cronbach's alpha for the fourteen-item OCB scale was 0.77

Control variables. Individuals' gender, age, education and tenure were included as control variables in our analyses.

\section{RESULT}

Hypotheses1 predicted that the above relationships between high performance work systems and in-role performance would be mediated by psychological contract breach. To test this hypothesis, I followed Baron and Kenny's (1986) recommendations for examining mediating effects in regression. They believed that mediation is demonstrated if three conditions are fulfilled: The first condition stipulates that 
the independent variable and the proposed mediator must each be significantly related to the dependent variable when considered separately. The preceding analyses in Table I demonstrated that the independent variable (high performance work systems) was significantly related to the four dependent variables (in-role performance, OCB, OCB-I, OCB-O), independent of the proposed mediators (psychological contract breach). To determine whether the proposed mediators were also related to the four dependent variables, the correlation matrix in Table I was examined. Table I shows that psychological contract breach was significant and negatively related to in-role performance, OCB, OCB-I, and OCB-O. Thus, psychological contract breach fulfilled the first condition as a potential mediator for four dependent variables.

TABLE I. MEANS, STANDARD DEVIATIONS, RELIABILITIES, AND INTERCORRELATIONS OF VARIABLES

\begin{tabular}{|c|c|c|c|c|c|c|c|c|}
\hline Variable & Mean & S.D. & 1 & 2 & 3 & 4 & 5 & 6 \\
\hline 1. HPWS & 3.50 & 0.56 & 1 & & & & & \\
\hline $2 . \mathrm{PCB}$ & 2.13 & 0.66 & $\begin{array}{c}- \\
.584 * *\end{array}$ & 1 & & & & \\
\hline $3 . \mathrm{IRP}$ & 4.06 & 0.54 & $.157^{* *}$ & $\begin{array}{c}- \\
.387^{* *}\end{array}$ & 1 & & & \\
\hline $4 . \mathrm{OCB}$ & 3.96 & 0.40 & $.259^{* *}$ & $\begin{array}{c}- \\
.383^{* *}\end{array}$ & $.749^{* *}$ & 1 & & \\
\hline $5 . \mathrm{OCB}-\mathrm{I}$ & 3.85 & 0.41 & $.270^{* *}$ & $\begin{array}{c}- \\
.200^{* *}\end{array}$ & $.443^{* *}$ & $.815^{* *}$ & 1 & \\
\hline $6 . \mathrm{OCB}-\mathrm{O}$ & 4.08 & 0.52 & $.184^{* *}$ & $\begin{array}{c}- \\
.429^{* *}\end{array}$ & $.798^{* *}$ & $.889^{* *}$ & $.459^{* *}$ & 1 \\
\hline
\end{tabular}

Note. $* \mathrm{p}<0.05 ; * * \mathrm{p}<0.01 ; * * * \mathrm{p}<0.001 . \quad(\mathrm{N}=630)$

The second condition requires the independent variable to be significantly related to the proposed mediator. This condition was tested by regressing psychological contract breach on the control variables and high performance work systems. As Table II reveals, high performance work systems was significant and negatively related to psychological contract breach. Hence, the proposed mediator met the second condition.

TABLE II. HIERARCHICAL REGRESSIONS PREDICTING THE IMPACT OF PSYCHOLOGICAL CONTRACT BREACH ON HIGH PERFORMANCE WORK SYSTEMS $(\mathrm{N}=630)$

\begin{tabular}{lcc}
\hline \multicolumn{1}{c}{ Variable } & Psychological contract breach \\
\hline Gender & $.070^{*}$ & -.013 \\
Age & .087 & .006 \\
Education & $-.090^{*}$ & $-.064^{*}$ \\
Tenure & .025 & .018 \\
HPWS & & $-.580^{* * *}$ \\
R2 & & \\
Change in R2 & .025 & .345 \\
$\mathrm{~F}$ & & .321 \\
$\mathrm{p}<0.05 ; * * \mathrm{p}<0.01 ; * * * \mathrm{p}<0.001$. & & $65.855^{* * *}$ \\
\hline
\end{tabular}

The last condition stipulates that the relationship between the independent variable and the dependent variable should be weaker or nonsignificant when the proposed mediator is in the regression equation than when the proposed mediator is not in the equation. To test this last condition, several regressions were performed for each dependent variable, with and without each of the potential mediating variables. TableIII, IV,V, and VI show the results.
TABLE III. HIERARCHICAL REGRESSIONS EXAMINING THE MEDIATING EFFECTS OF PSYCHOLOGICAL CONTRACT BREACH ON RELATIONSHIPS BETWEEN HIGH PERFORMANCE WORK SYSTEMS AND IN-ROLE PERFORMANCE $(\mathrm{N}=630)$

\begin{tabular}{llll}
\hline \multicolumn{1}{c}{ Variable } & \multicolumn{3}{c}{ In-role performance } \\
\hline Step1 & & $.078^{*}$ & $.073^{*}$ \\
Gender & .052 & .080 & .082 \\
Age & .054 & $.086^{*}$ & .057 \\
Education & $.094 *$ & .049 & .057 \\
Tenure & .047 & & \\
Step2 & & $.183 * * *$ & -.076 \\
HPWS & & & $-.446 * * *$ \\
Step 3 & & .052 & .182 \\
PCB & & .032 & .130 \\
R2 & .02 & $6.824 * * *$ & $23.067 * * *$ \\
Change in R2 & &
\end{tabular}

When in-role performance was regressed on high performance work systems, gender, age, education, job and tenure were entered at first, then high performance work systems was entered in step 2, and was found to be significant and positively related to in-role performance $(\beta=0.183, \mathrm{p}<0.001)$. In step 3 , psychological contract breach was added to the equation, and psychological contract breach was significant and negative $(\beta=-0.446, p<0.001)$, while high performance work systems was nonsignificance. Taken together, these results indicate that psychological contract breach fully mediated the relationship between high performance work systems and in-role performance, which supports $\mathrm{H} 1$.

When OCB was regressed on high performance work systems, gender, age, education, job and tenure as control variable entered the equation in step 1 , then high performance work systems entered in step2 and was found to be significant and positively related to OCB $(\beta=0.288, p<0.001)$. Next, when psychological contract breach was added to the equation, it was found to be significant and negative $(\beta=-0.358, \mathrm{p}<0.001)$, whereas high performance work systems was no longer significant. Thus, psychological contract breach fully mediated the relationship between high performance work systems and OCB. H2 was fully supported.

TABLE IV. HIERARCHICAL REGRESSIONS EXAMINING THE MEDIATING EFFECTS OF PSYCHOLOGICAL CONTRACT BREACH ON RELATIONSHIPS BETWEEN HIGH PERFORMANCE WORK SYSTEMS AND OCB(N=630)

\begin{tabular}{|c|c|c|c|}
\hline Variable & \multicolumn{3}{|c|}{ OCB } \\
\hline Step1 & & & \\
\hline Gender & .002 & .043 & .039 \\
\hline Age & .041 & .082 & .084 \\
\hline Education & .032 & .019 & -.004 \\
\hline Tenure & .089 & .092 & .099 \\
\hline Step2 & & & \\
\hline HPWS & & $.288 * * *$ & .080 \\
\hline Step 3 & & & \\
\hline PCB & & & $-.358 * * *$ \\
\hline $\mathrm{R} 2$ & .015 & .094 & .178 \\
\hline Change in $\mathrm{R} 2$ & & .079 & .084 \\
\hline $\mathrm{F}$ & $2.452 *$ & $13.011 * * *$ & $22.511 * * *$ \\
\hline
\end{tabular}


TABLE V. HIERARCHICAL REGRESSIONS EXAMINING THE MEDIATING EFFECTS OF PSYCHOLOGICAL CONTRACT BREACH ON RELATIONSHIPS BETWEEN High PERFORMANCE WORK SYSTEMS AND OCB-I（N=630）

\begin{tabular}{llll}
\hline \multicolumn{1}{c}{ Variable } & \multicolumn{2}{c}{ OCB-I } \\
\hline Step1 & & & \\
Gender & -.052 & -.010 & -.011 \\
Age & .070 & $.111^{*}$ & $.112^{*}$ \\
Education & -.007 & -.020 & -.025 \\
Tenure & .065 & .068 & .069 \\
Step2 & & & \\
HPWS & & $.294^{* * *}$ & $.251^{* * *}$ \\
Step 3 & & \\
PCB & & \\
& & & -.073 \\
& & & \\
R2 & .018 & .100 & .104 \\
Change in R2 & & .082 & .004 \\
F & $2.834^{*}$ & $13.895^{* * *}$ & $12.014^{* * * *}$ \\
\hline$<0.05 ; * * \mathrm{p}<0.01 ; * * * \mathrm{p}<0.001$. & &
\end{tabular}

To test H2a, OCB-I was regressed on high performance work systems, gender, age, education, job and tenure as control variable entered the equation in step 1 , then high performance work systems entered next and was found to be significant and positively related to OCB-I $(\beta=0.294, \mathrm{p}<0.001)$. In step 3 , when psychological contract breach was added to the equation, it was found to be nonsignificance. Therefore, psychological contract breach didn't mediate the relationship between high performance work systems and OCB-I. H2a was not supported.

To test $\mathrm{H} 2 \mathrm{~b}, \mathrm{OCB}-\mathrm{O}$ was regressed on high performance work systems, gender, age, education, job and tenure as control variable entered the equation at first. In step2 high performance work systems entered next and was found to be significant and positively related to OCB-O $(\beta=0.209, p<0.001)$. In step 3, when psychological contract breach was added to the equation, it was found to be significant and negative $(\beta=-0.490, \mathrm{p}<0.001)$, whereas high performance work systems was no longer significant. Thus, psychological contract breach fully mediated the relationship between high performance work systems and OCB-O, which fully supported $\mathrm{H} 2 \mathrm{~b}$.

TABLE VI. HIERARCHICAL REGRESSIONS EXAMINING THE MEDIATING EFFECTS OF PSYCHOLOGICAL CONTRACT BREACH ON RELATIONSHIPS BETWEEN HIGH PERFORMANCE WORK SYSTEMS AND OCB-O（N=630）

\begin{tabular}{llll}
\hline \multicolumn{1}{c}{ Variable } & \multicolumn{1}{c}{ OCB-O } \\
\hline Step1 & & & \\
Gender & .044 & .074 & .068 \\
Age & .008 & .037 & .040 \\
Education & .055 & .045 & .014 \\
Tenure & .085 & .087 & .096 \\
Step2 & & & \\
HPWS & & $.209 * * *$ & -.075 \\
Step 3 & & & $-.490^{* * *}$ \\
PCB & & & \\
& & & .211 \\
R2 & .013 & .054 & .157 \\
Change in R2 & & .041 & $27.849 * * *$ \\
$\mathrm{~F}$ & $1.995^{*}$ & $7.161 * * *$ & \\
$\mathrm{p}<0.05 ; * * \mathrm{p}<0.01 ; * * * \mathrm{p}<0.001$. & &
\end{tabular}

Taken together, this set of regression equations indicates that psychological contract breach fully mediated the relationship between high performance work systems and employee performance.

\section{DISCUSSION}

Although there is considerable evidence that high performance work systems are associated with organizational performance (Appelbaum et al., 2000; Arthur, 1994), the research on relationship between high performance work systems and employee performance is limited. The results from this study add to previous research by suggesting that high performance work systems impact the in-role performance and $\mathrm{OCB}$, so that the cohesion of the best human resource management practices will motivate the employee to contribute to organization.

Specifically, the results indicate that organizational investments in high performance work systems are associated with fewer perceptions of psychological contract breach. Previous studies have found that unmet expectations can have an adverse impact upon outcomes of organizational interest, such as citizenship behavior, job satisfaction, and intentions to quit, and the findings from this study suggest that high performance work systems may serve an important role in keeping employees from experiencing such adverse reactions.

Moreover, the results indicate high performance work systems influence employee performance via perceptions of psychological contract breach, which add to previous research on mechanisms between high performance work systems and employee performance. The results highlight the importance of psychological contract in areas of human resource management and employee relationship management.

At last, this study did not address causality due to its use of cross-sectional data, future research would benefit from longitudinal data and/or data from multiple sources, such as managers or peers.

\section{REFERENCES}

[1] Appelbaum, E., Bailey, T., Berg, P. and Kalleberg, A., Manufacturing Advantage: Why High-Performance Work Systems Pay Off, Cornell University Press, Ithaca, NY.2000.

[2] Arthur, J.B.,Effects of human resource systems on manufacturing performance and turnover, Academy of Management Journal, Vol. 37 No. 3, 1994,pp. 670-687.

[3] Baron, R.M., and Kenny, D.A.,The Moderator-Mediator Variable Distinction in Social Psychological Research: Conceptual, Strategic, and Statistical Considerations,Journal of Personality and Social Psychology, Vol.51 No. 6,1986,pp.1173-1182.

[4] Becker, B. and Huselid, M., Strategic human resource management: where do we go from here?, Journal of Management, Vol. 32 No. 6,2006 ,pp. 898-925.

[5] Blomme, R. J., A. van Rheede, and D. M. Tromp. The Use of the Psychological Contract to Explain Turnover Intentions in the Hospitality Industry: A Research Study on the Impact of Gender on the Turnover Intentions of Highly Educated Employees.International Journal of Human Resource Management, Vol.21 No.1,2010,pp.144-162.

[6] Bowen, D. and Ostroff, C. ,Understanding HRM-firm performance linkages: the role of the "strength" of the hrm system, Academy of Management Review, Vol. 29 No. 2,2004,pp. 203-221.

[7] Boxall, P. and Macky, K., Research and theory on high-performance work systems: progressing the high-involvement stream, Human Resource Management Journal, Vol. 19 No. 1, 2009,pp. 3-23.

[8] Chen, Z. X., A. S. Tsui, and L. Zhong,Reactions to Psychological Contract Breach: A Dual Perspective.Journal of Organizational Behavior Vol.29 No.5,2008,pp.527-548. 
[9] Delaney, J.T., and Huselid, M.A., The Impact of Human Resource Management Practices on Perceptions of Organizational Performance,Academy of Management Journal, 39, 1996,pp.949-969.

[10] Delery, J. ,Issues of fit in strategic human resource management: implications for research, Human Resource Management Review, Vol. 8 No.3,1998 pp. 289-309.

[11] Delery, J.E., and Doty, D.H., Modes of Theorizing in Strategic Human Resource Management: Tests of Universalistic, Contingency, and Configurational Performance Predictors, Academy of Management Journal, Vol.39 No.4,1996,pp.802-835.

[12] Huselid, M.A. , Impact of human resource management practices on turnover, productivity, and corporate financial performance, Academy of Management Journal, Vol. 38 No.3, 1995,pp. 635-672.

[13] Koene, B.A.S. and Van Riemsdijk, M. , Managing temporary workers: work identity, diversity and operational HR choices, Human Resource Management Journal, Vol. 15 No. 1,2005, pp. 76-92.

[14] Lester, S.W., Turnley, W.H., Bloodgood, J.M., and Bolino, M.C. , Not Seeing Eye to Eye: Differences in Supervisor and Subordinate Perceptions of and Attributes for Psychological Contract Breach,Journal of Organizational Behavior, Vol.23 No. 1, 2002,pp.39-56.

[15] Macky, K. and Boxall, P.,The relationship between 'high performance work practices' and employee attitudes: an investigation of additive and interaction effects, International Journal of Human Resource Management, Vol. 18 No. 4, 2007,pp. 537-567.

[16] Orvis, K. A., N. M. Dudley, and J. M. Cortina. . Conscientiousness and Reactions to Psychological Contract Breach: A Longitudinal Field Study. Journal of Applied Psychology Vol. 93 No. 5, 2008,pp.1183-1193.

[17] Paauwe, J. and Boselie, J.P., HRM and performance: what next?, Human Resource Management Journal, Vol. 15 No. 4, 2005pp. 68-83.

[18] Robinson, S.L.,Trust and Breach of the Psychological Contract,Administrative Science Quarterly, Vol. 41No. 4,1996 ,pp.574599.

[19] Robinson, S.L., Kraatz, M.S. and Rousseau, D.M. , Changing obligations and the psychological contract: a longitudinal study, Academy of Management Journal, Vol. 37 No.1, 1994,pp. 137-153.

[20] Robinson, S.L. and Morrison, E.W. , The development of psychological contract breach and violation: a longitudinal study, Journal of Organizational Behavior, Vol. 21, 2000,pp. 525-546.

[21] Rousseau,D.M.,Psychological Contracts in Organizations:Understanding Written andUnwritten Agreements, Sage, London.1995.
[22] Rousseau, D.M. and McLean Parks, J., The contracts of individuals and organizations, in Cummings, L.L. and Staw, B.M. (Eds), Research in Organizational Behavior, JAI Press, Greenwich, CT.1993.

[23] Schuler, R.S. and Jackson, S.E. , Linking competitive strategies with human resource management practices, The Academy of Management Executive, Vol. 1 No. 3,1987 ,pp. 207-219.

[24] Sparrow, P.R. , Reappraising psychological contracting, International Studies of Management and Organization, Vol. 28 No.1, 1998,pp. 30-61.

[25] Suazo, M. M. . The Mediating Role of Psychological Contract Violation on the Relations Between Psychological Contract Breach and WorkRelated Attitudes and Behaviors. Journal of Management Psychology Vol24 No.2,2009,pp.136-160.

[26] Tekleab, A.G. and Taylor, M.S. , Aren't there two parties in an employment relationship? Antecedents and consequences of organization-employee agreement on contract obligations and violations, Journal of Organizational Behavior, Vol. 24 No.5,2003, pp. 585-608.

[27] Turnley, W.H., Bolino, M.C., Lester, S.W., and Bloodgood, J.M. , The Impact of Psychological Contract Fulfillment on the Performance of InRole and Organizational Citizenship Behaviors,Journal of Management, Vol. 29 No.2, 2003,pp.187-206.

[28] Turnley, W.H. and Feldman, D.C. , Re-examining the effects of psychological contract violations: unmet expectations and job dissatisfaction as mediators, Journal of Organizational Behavior, Vol. 21 No.1, 2000,pp. 25-42.

[29] Westwood, R., Sparrow, P. and Leung, A., Challenges to the psychological contract in Hong Kong, International Journal of Human Resource Management, Vol. 12 No.4, 2001,pp. 621-652.

[30] Williams, L. J., and Anderson, S. E. .Job satisfaction and organizational commitment as predictors oforganizational citizenship and in-role behaviors. Journal of Management, Vol.17 No.3, 1991,pp.601-617.

[31] Wright, P.M., Gardner, T.M., Moynihan, L.M. and Allen, M.R. , The relationship between HR practices and firm performance: examining causal order, Personnel Psychology, Vol. 58, No. 2, 2005,pp. 409-446.

[32] Xiao, Zhixing \& Björkman, Ingmar. . High Commitment Work Systems in ChineseOrganizations: A Preliminary Measure. Management and Organization Review, Vol.2 No.3,2006, pp.403-422.

[33] Zhao, H., Wayne, S.J., Glibkowsky, B.C. and Bravo, J. , The impact of psychological contract breach on work-related outcomes: a metaanalysis, Personnel Psychology, Vol. 60 No. 3, 2007,pp. 647-680. 